\title{
Degradation of net primary production in a semiarid rangeland
}

\author{
Hasan Jackson and Stephen D. Prince \\ University of Maryland, College Park, Maryland 20742, USA \\ Correspondence to: Hasan Jackson (hjackso1@umd.edu)
}

Received: 10 December 2015 - Published in Biogeosciences Discuss.: 21 January 2016

Revised: 28 June 2016 - Accepted: 25 July 2016 - Published: 23 August 2016

\begin{abstract}
Anthropogenic land degradation affects many biogeophysical processes, including reductions of net primary production (NPP). Degradation occurs at scales from small fields to continental and global. While measurement and monitoring of NPP in small areas is routine in some studies, for scales larger than $1 \mathrm{~km}^{2}$, and certainly global, there is no regular monitoring and certainly no attempt to measure degradation. Quantitative and repeatable techniques to assess the extent of deleterious effects and monitor changes are needed to evaluate its effects on, for example, economic yields of primary products such as crops, lumber, and forage, and as a measure of land surface properties which are currently missing from dynamic global vegetation models, assessments of carbon sequestration, and land surface models of heat, water, and carbon exchanges. This study employed the local NPP scaling (LNS) approach to identify patterns of anthropogenic degradation of NPP in the Burdekin Dry Tropics (BDT) region of Queensland, Australia, from 2000 to 2013. The method starts with land classification based on the environmental factors presumed to control (NPP) to group pixels having similar potential NPP. Then, satellite remotely sensing data were used to compare actual NPP with its potential. The difference in units of mass of carbon and percentage loss were the measure of degradation. The entire BDT $\left(7.45 \times 10^{6} \mathrm{~km}^{2}\right)$ was investigated at a spatial resolution of $250 \times 250 \mathrm{~m}$. The average annual reduction in NPP due to anthropogenic land degradation in the entire BDT was $-2.14 \mathrm{MgC} \mathrm{m}^{-2} \mathrm{yr}^{-1}$, or $17 \%$ of the non-degraded potential, and the total reduction was $-214 \mathrm{MgC} \mathrm{yr}^{-1}$. Extreme average annual losses of $524.8 \mathrm{gC} \mathrm{m}^{-2} \mathrm{yr}^{-1}$ were detected. Approximately $20 \%$ of the BDT was classified as "degraded". Varying severities and rates of degradation were found among the river basins, of which the Belyando and Suttor were highest. Interannual, negative trends in reductions of NPP occurred in $7 \%$ of the entire region, indicating
\end{abstract}

ongoing degradation. There was evidence of areas that were in a permanently degraded condition. The findings provide strong evidence and quantitative data for reductions in NPP related to anthropogenic land degradation in the BDT.

\section{Introduction}

Land degradation is a deleterious process in which unfavorable conditions for humans occur (Pickup, 1998, 1996; Safriel, 2007; Safriel and Adeel, 2005) as a result of direct and indirect human and natural processes. In drylands (aridity index $<0.65$ ), poor land management such as excessive cultivation, overgrazing, and unmanaged fires have farreaching effects on biogeophysical processes (Prince, 2002). While degradation is always undesirable, there is evidence that, in some cases, it cannot be reversed (Prince, 2016) when the causes are removed - a much more serious outcome. However, it is not known how widespread this condition is. There are many other aspects of dryland degradation that are little understood, including its location, severity, and actions needed for remediation (Reynolds et al., 2007) or, at least, to prevent a net increase (Lal et al., 2012; UNCCD, 2012). The extent of soil or pasture degradation through overgrazing, anywhere in the world, has been estimated by experts' subjective opinion, rather than systematic quantitative criteria (Gifford, 2010).

"Degradation" implies an undesirable condition compared with a starting point (Prince, 2016), but degraded compared to what? To detect a relative condition, a reference is needed, in this case not degraded (Bastin et al., 2012; Boer and Smith, 2003; Prince et al., 2007; Stoms and Hargrove, 2000) without which states of degradation have no meaning. However, the detection of non-degraded reference sites that are at their potential is problematic (Wessels et al., 2007). There are several 


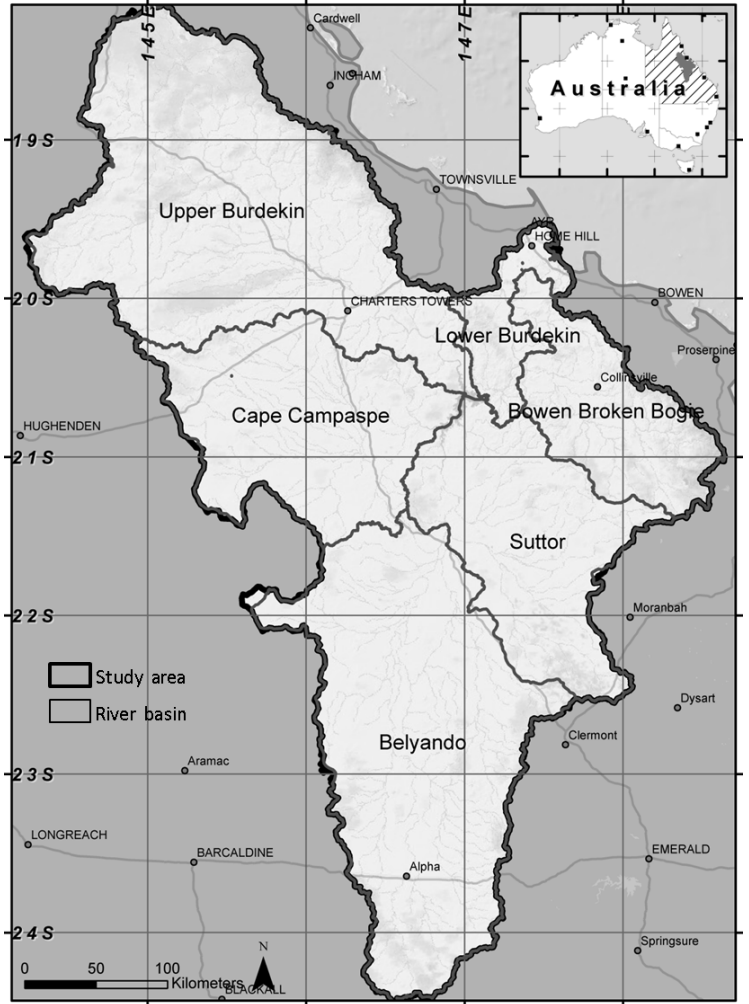

Figure 1. Location of the Burdekin Dry Tropics (BDT) region in the state of Queensland, Australia, the six major river basins, and major roads and towns.

approaches that seem reasonable but have severe limitations, particularly when applied to large areas: visual assessment of satellite imagery is entirely subjective and therefore unrepeatable; field surveys, such as the National Resources Inventory (Nusser and Goebel, 1997), are limited to small areas (Budde et al., 2004; O'Connor et al., 2001; Prince, 2004) that can be assessed by an evaluator on the ground; and process modeling of potential production followed by comparison with actual production (Bai et al., 2008; Boer and Puigdefabregas, 2005) suffers from the need for data and parameters that are generally not available (Prince, 2002).

The particular type of degradation investigated here is anthropogenic reduction of net primary production (NPP), which, in addition to its own importance, is an indicator of a wider range of degradative processes (Prince, 2002) such as soil compaction, salinization, and water and wind erosion that generally also reduce NPP (Pickup, 1996; Walker and Janssen, 2002). The objective of this study was to identify and characterize the extent and severity of degradation of vegetation productivity in the extensive rangelands, in excess of $10000 \mathrm{~km}^{2}$, of the Burdekin Dry Tropics (BDT) in Queensland, Australia. The local NPP scaling (LNS) method (Prince, 2004; Prince et al., 2009; Wessels et al., 2008) was used to address the problem of identification of reference sites. LNS starts with classification of the region into land capability classes (LCCs) in which the biogeophysical environment is, as near as possible, the same, so assessments are made with areas of the same type and potential. The reference NPP is identified as the maximum value in each LCC, then the comparisons are made with this standard. Inaccuracies and even invalidity of the LNS technique can arise under certain conditions, although some methods are available that can minimize these, but they can never be entirely prevented. On the other hand, bearing in mind the fundamental requirement for non-degraded comparison, and also that there is currently no other method available, LNS was used.

Specifically, this study (1) identified the spatial extent of non-degraded and degraded land, (2) distinguished significant land trends in interannual reductions in NPP, and (3) linked total NPP reductions to specific land processes and states in the BDT.

\section{Material and methods}

\subsection{Study area}

The BDT region is located in northern Queensland, Australia, and covers approximately $7.45 \times 10^{6} \mathrm{~km}^{2}$. The terrain is largely flat with gradually increasing elevation inland (Mellick and Hanlon, 2005). Six large river basins are contained in the BDT (Fig. 1): the Upper Burdekin $\left(2.26 \times 10^{6} \mathrm{~km}^{2}\right)$, Belyando $\left(2.08 \times 10^{6} \mathrm{~km}^{2}\right)$, Cape Campaspe $\left(1.18 \times 10^{6} \mathrm{~km}^{2}\right)$, Suttor $\left(1.07 \times 10^{6} \mathrm{~km}^{2}\right)$, Bowen Broken Bogie $\left(0.63 \times 10^{6} \mathrm{~km}^{2}\right)$, and Lower Burdekin $\left(0.23 \times 10^{6} \mathrm{~km}^{2}\right)$. Average seasonal rainfall varies spatially from 400 to $1500 \mathrm{~mm}$ with a steep decreasing gradient from the coast inland. More than $70 \%$ of rainfall falls during summer months (December-February) and runoff variability is high (Petheram et al., 2008; Rustomji et al., 2009). Discharge from rivers and creeks occurs in large pulses associated with intense but brief storms. During the study from 2000 to 2013, years with low (e.g., 2002-2007; $\leq 500 \mathrm{~mm} \mathrm{yr}^{-1}$ ) and high (e.g., 2008-2012; $\geq 600 \mathrm{~mm} \mathrm{yr}^{-1}$ ) accumulations occurred (Fig. 2).

In the BDT, NPP is strongly influenced by regional variations in moisture availability (Hutley et al., 2000), fire frequency (Beringer et al., 2007), and soil properties. Native vegetation varies from dense to sparse forest to shrubland and open grassland. Approximately $83 \%$ of the BDT is savanna consisting of mixed grass and trees. There are smaller areas that consist exclusively of shrubs (1\%), grasses $(8 \%)$, or rain-fed crops $(8 \%)$. The ratio of tree cover to grass cover is a defining attribute that differentiates local environments in savanna ecosystems (Accatino et al., 2010). The croplands, both irrigated and rain-fed, are found in northeastern, higher rainfall areas.

The major land use (85-90\% of the BDT) is livestock production on unimproved pastures (Mellick and Hanlon, 2005). According to the State of Queensland (2011), approximately 


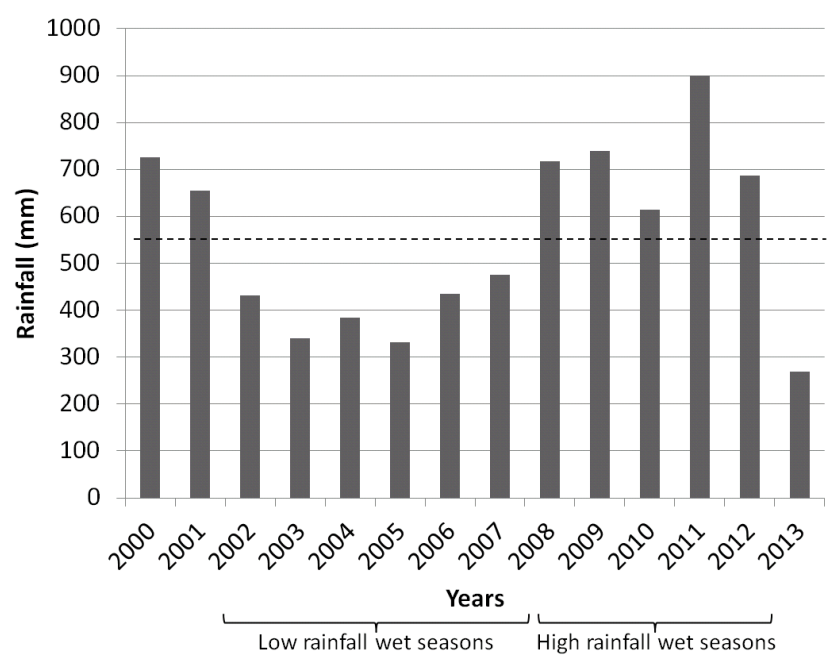

Figure 2. Annual average rainfall in BDT for 2000-2013. The dashed line is the 14-year average.

$12 \%$ of the BDT has grazing practices likely to result in degradation.

\subsection{Land capability classification}

Land capability classes (LCCs) are areas that are homogeneous with respect to the selected environmental factors. The factors used here were meteorological, soil, and vegetation. The Australian Bureau of Meteorology distributes daily, synoptic weather reports consisting of rainfall (Weymouth et al., 1999), minimum and maximum temperature, water vapor pressure deficit at 09:00 and 15:00, and solar exposure (Jones et al., 2009), gridded at $5 \times 5 \mathrm{~km}$ spatial resolution. Daily inputs were summed for the growing season from November to April and rescaled to $250 \times 250 \mathrm{~m}$ using a nearest-neighbor interpolation. Data from three national-scale, $1 \times 1 \mathrm{~km}$, gridded, soil property maps (ACLEP, 2011) were used: (1) plant available water-holding capacity, calculated as the sum of the water-holding capacity of the A and B soil horizons (0 to $1 \mathrm{~m})$; (2) clay content ( 0 to $0.3 \mathrm{~m}$ ); and (3) soil bulk density (0 to $0.3 \mathrm{~m}$, spanning $\mathrm{A}$ and $\mathrm{B}$ horizons) as a measure of porosity. Foliage projective cover (FPC) was obtained from Danaher et al. (2004), although it was only available for one year prior to the study period. Pixels with over 50\% FPC (mostly dense tropical forest) were not included.

A $k$-means unsupervised clustering was used to classify meteorological data, soil properties, and FPC for each growing season. To ensure equal numerical weighting, all environmental data were normalized prior to clustering. The environmental data were then partitioned using unsupervised clustering $(n=50$, maximum iterations $=100$, change threshold $=0.05 \%$, minimum of 1000 pixels), which resulted in 50 clusters. These are referred to as UMD land capability classes (UMDLCC). The pixels found within each homogeneous UMDLCC were examined using linear regression and Person correlation to determine whether any underlying relationships remained between NPP and the environmental data used to create them. Only LCCs where the correlation was below 0.4 were included in the final UMDLCC for that year. Pixels with correlations above 0.4 were reclassified. This procedure was repeated for each year.

Few maps exist that could be used for validation of the homogeneity of LCCs in the BDT. One such is the grazing land management (GLM) land types map (DPI\&F, 2004; Whish, 2011), which classifies areas based on vegetation, soil, and terrain characteristics to create static types within which the response to grazing pressure is similar. Since the principles used to create GLM were similar to those of the UMDLCCs, an additional LNS was performed using GLM land types (GLMLCC). The vector GLM map was converted to a raster format at a $250 \times 250 \mathrm{~m}$ spatial resolution. GLM land types consisting of fewer than 1000 pixels were removed, resulting in 50 GLMLCCs - the same number of LCCs as the UMDLCC. These were compared with the UMDLCC.

The two LCCs were compared using the mean square variance of their maximum NPP to determine the extent to which each reduced within-LCC variance and maximized betweenLCC variance. Interannual wet season rainfall (November to April) was averaged throughout the BDT (Fig. 2), and then compared with the two variance components of both UMDLCC and GLMLCC. A paired $t$ test was used to determine whether there were significant differences in withinLCC and between-LCC variance in maximum NPP for the two LCCs.

A second comparison was made using the Vegetation Assets, States and Transitions (VAST) classification of Australia, version 2 (Lesslie et al., 2010). VAST is a national level map of changes to vegetation since European settlement, which began in 1750, showing the degree of anthropogenic modification of native vegetation until 2011. VAST uses the following classes: wilderness, biophysical naturalness, land use, land cover, and extent of native vegetation. There are four classes of increasing human modification: 1, "modified"; 2, "transformed"; 3, "replaced"; and 4, "removed". Areas without naturally occurring native vegetation are designated 5 ("bare") and areas with no change 0 ("residual").

Erosion is strongly linked to land degradation in drylands (Lal, 2003; Ravi et al., 2010), and this is the case in Australian rangelands (Bui et al., 2011; Dregne, 1995; Gillieson et al., 1996; Webb et al., 2009). A database of erosion was used to better understand the nature of the degradation that was detected. Four environmental variables related to natural and human-related erosion processes were used: sediment load at $500 \times 500 \mathrm{~m}$ (NLWRA, 2002); soil erodibility, rainfall erosivity, and hillslope erosion, each at $250 \times 250 \mathrm{~m}(\mathrm{Lu}$ et al., 2001); and gully density at $500 \times 500 \mathrm{~m}$ (Hughes et al., 2001). Gully density and sediment load were downscaled from their original spatial resolutions to $250 \times 250 \mathrm{~m}$ using a nearest-neighbor interpolation. 


\subsection{Measurement of NPP using satellite data}

Moderate Resolution Imaging Spectrometer (MODIS) NPP data (MOD17A3) (Running et al., 2004) were obtained from the Land Processes Distributed Active Archive Center satellite data archives (http://modis.gsfc.nasa.gov/data/). These data have $1 \times 1 \mathrm{~km}$ resolution and so, to maintain the highest possible spatial resolution, the data were rescaled to $250 \times 250 \mathrm{~m}$ using coefficients of the regression of growing season $250 \times 250 \mathrm{~m}$ normalized difference vegetation index (NDVI; MOD13Q1) on $1 \times 1 \mathrm{~km}$ NDVI (MOD13A2).

LNS is spatially and temporally scale-dependent since the NPP in a pixel is the sum of its finer-scale components and is calculated for individual years over a 14-year period. Therefore, in this application, degradation at finer spatial and temporal scales than $250 \times 250 \mathrm{~m}$ and 14 years may have been missed, as would any pattern of LNS at finer scales (such as confinement of degradation to small but repeated ridges in a tributary). While this might be a drawback for fine-scale applications, such as the effects of livestock congregation at water and gates, in the BDT, livestock management is normally applied to areas large enough to contain at least several $250 \times 250 \mathrm{~m}$ pixels. Other limitations for which there are no perfect solutions include the effect of gradients in environmental factors, such as meteorological variables, that are dissected by the classification into arbitrary ranges. Pixels are more likely to be selected as the potential sites if they are in the most favorable part of the gradient, often at the edge of LCC. While this effect is minimized using a large number of LCCs, it cannot be removed entirely. A warning situation would be if reference pixels were confined to one part of an LCC. In all of these cases, care is needed to review the LCCs using alternative sources such as high-resolution imagery that can provide visual warning. Additional limitations can arise if small features occur that are not large enough to be placed in a different LCC, or in cases where the entire LCC is degraded or entirely non-degraded. Various methods can be used to minimize these and other problems, but they cannot all be entirely prevented and in some cases the extent of the effect cannot be measured.

\subsection{Local net primary production scaling (LNS)}

LNS values are the difference between each pixel and its reference NPP (Fig. 3). It is therefore zero (equal to the reference NPP, i.e., not degraded) or negative (below the reference, i.e., degraded). The LNS values can be expressed as the actual reduction of NPP in $\mathrm{gC} \mathrm{m}^{-2} \mathrm{yr}^{-1}$ or as a percentage of the reference. LNS was calculated for each year (20002013), producing 14 LNS maps, using both the UMDLCC and GLMLCC maps.

The potential, non-degraded reference NPP was obtained using the frequency distribution of NPP in each LCC (Fig. 3). The 85th percentile was arbitrarily selected as the best estimator. Pixels with NPP higher than the reference, possibly

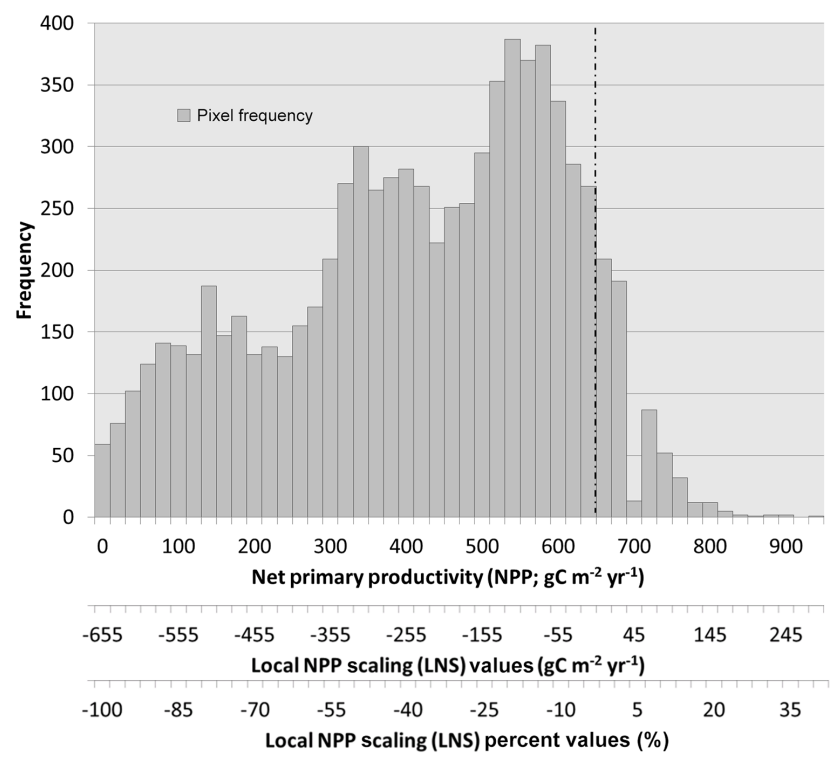

Figure 3. Example of the use of the frequency distribution of NPP of pixels in a single land capability class (LCC) to calculate local NPP scaling (LNS) values. The vertical line denotes the reference NPP at the 85 percentile of the distribution. The abscissa is labeled in LNS, NPP, and percentage LNS units.

caused by residual pixels with high NPP in areas that were not typical of the rest of the LCC, were omitted. A possible limitation of LNS is if no pixels are at their maximum; the reference would then be below the true potential. This effect was minimized by masking rivers, open water, roads, human settlements, and other human land features not representative of the LCC, but it cannot be entirely eliminated and so interpretation of the results must take this into account.

LNS percent values were averaged from 2000 to 2013 to determine the mean NPP reduction for each pixel over the 14 years. To facilitate discussion, values that were $\leq$ $-30 \%$ were arbitrarily classified as "degraded", while for all other pixels, those where LNS was between 0 and $-29 \%$ were classified as "non-degraded". A time series of annual LNS percent values for every pixel was used to identify significant $(\alpha<0.10)$ interannual trends in LNS over the 14 years. Pixels were classified according to their trends into three categories: (1) no significant interannual trends ("no LNS trend"), (2) significant positive interannual trends ("positive LNS trend"), and (3) significant negative interannual trends ("negative LNS trend"). The trend classification was combined with the two levels of degradation to create six classes: (1) "non-degraded and positive LNS trends", (2) "non-degraded and no LNS trend", (3) "non-degraded and negative LNS trend", (4) "degraded and positive LNS trend", (5) "degraded and no LNS trend", and (6) "degraded and negative LNS trend".

Spatial agreement between average LNS values and ecological indicators related to land condition (e.g., hillslope and 
gully erosion) or susceptibility to poor condition (e.g., rainfall erosivity and soil erodibility) were examined using Cohen's kappa ( $\kappa$ ) fuzzy numeric (Cohen, 1960). This elaboration of the simple kappa test includes "near misses" and accounts for coincidences that occur by chance. Values range from 0.0 to 1.0 with increasing agreement. All kappa calculations were performed using the Map Comparison Kit (Visser and de Nijs, 2006).

\section{Results}

\subsection{UMDLCC}

The average number of pixels per UMDLCC varied each year from $3182\left(0.01 \times 10^{6} \mathrm{~km}^{2}\right)$ in 2004 to 141690 $\left(0.56 \times 10^{6} \mathrm{~km}^{2}\right)$ in 2013 . Their locations differed each year owing to interannual differences in weather patterns. Approximately half were non-contiguous, interspersed between other LCCs, but generally in no more than two river basins. Most reference pixels were selected in more than one year and a small number were selected in all years.

The interannual, between-LCC variance in reference NPP was higher for UMDLCC compared with GLMLCC. Conversely, within-LCC variance for UMDLCC was lower than for GLMLCC, indicating that the pixels selected as reference within UMDLCCs were more homogeneous than GLMLCC and more distinct between. A paired $t$ test showed that these differences were significant (Table 1),

Interannual rainfall was significantly related to betweenLCC and within-LCC variance in reference NPP for both LCCs (Fig. 4), accounting for nearly equal proportions of within-LCC variance in reference NPP for UMDLCC and GLMLCC (Fig. 4b), but between-LCC variance was better accounted for by UMDLCC $(81 \%)$ than for GLMLCC (66\%; Fig. 4a).

The comparison of UMDLCC and the VAST land classification, albeit based on different data and aims, provided an independent comparison. In total, $35.8 \%$ of UMDLCC reference pixels were in the VAST "residual" class that has, theoretically, been undisturbed since 1750 . The remaining $64.2 \%$ were in classes with varying degrees of vegetation changes from native pasture: 1, "modified" (29.6\%); 2, "transformed" (19.2\%); and 3, "replaced" (15.3\%). The remaining reference sites, less than $1 \%$, were in classes 4 ("removed") or 5 ("bare") with LCCs where all pixels were degraded or have been caused by inadequate or inaccurate data used to create the LCCs, errors in the VAST classification, or a result of re-gridding VAST pixels from $1 \times 1 \mathrm{~km}$ to $250 \times 250 \mathrm{~m}$ spatial resolution.
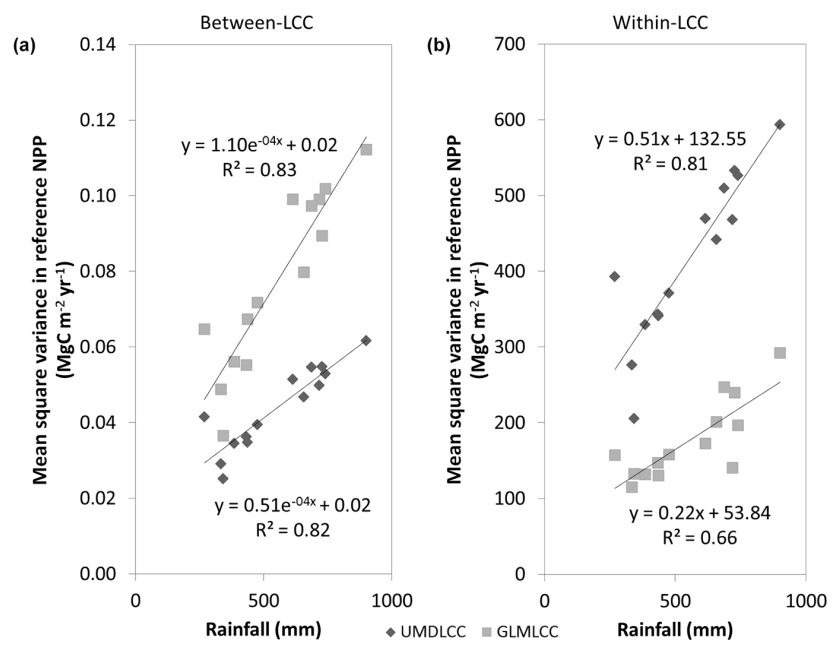

Figure 4. Mean square variance in reference NPP $\left(\mathrm{MgC} \mathrm{m}^{-2} \mathrm{yr}^{-1}\right)$ for UMDLCC and GLMLCC in relation to rainfall: (a) "betweenLCC" and (b) "within-LCC" with best-fit regression lines for each year 2000 to 2013 .

\subsection{LNS}

The $-30 \%$ LNS percent value used to differentiate "degraded" areas from "non-degraded" areas was equivalent to an average annual reduction in NPP of $-169.6 \mathrm{gC} \mathrm{m}^{-2} \mathrm{yr}^{-1}$ ( standard deviation $=25.5$ ). Between 2000 and 2013 the average annual LNS across the entire BDT, including both "degraded" and "non-degraded" areas, was $-2.14 \mathrm{MgC} \mathrm{m}^{-2} \mathrm{yr}^{-1}$ (Table 2). The average reduction in "degraded" areas was more than twice that in the "nondegraded" areas and the LNS of the positive LNS trend class was lower than the negative and no LNS trends.

The sum of LNS values for an entire class, as opposed to the LNS value per unit area, revealed the importance of class size in contributing to the overall reduction in NPP. The "degraded" class had a total reduction in NPP of $-1.1 \mathrm{GgC}$ from 2000 to 2013 and occupied $1.46 \times 10^{6} \mathrm{~km}^{2}$ (Table 3). The larger area occupied by the "non-degraded" class resulted in a greater total reduction in NPP $(-1.9 \mathrm{GgC}$; Table 3$)$, although much less severe reduction in NPP per unit area (Table 2). In the same way, non-degraded areas with no LNS trend were by far the greatest total reduction in NPP owing to the large area occupied by this class.

The majority of degraded pixels had LNS values between -30 and $-49 \%$, with only a small proportion below $-50 \%$. The largest number of the non-degraded pixels were in the -10 to $-29 \%$ LNS classes. For the degraded pixels, the average LNS in NPP units was less than half that of the nondegraded pixels (Tables 4 and 5). Similarly, reductions in NPP as a percent of the reference were lower (more severe) for degraded than non-degraded pixels. 
Table 1. Mean, standard deviation, and $t$ test of mean square variance of reference NPP $\left(\mathrm{gC} \mathrm{m}^{-2} \mathrm{yr}^{-1}\right)$ for UMDLCC and GLMLCC, partitioned into between-LCC and within-LCC.

\begin{tabular}{lccccc}
\hline \multirow{2}{*}{ Mean square variance } & \multicolumn{2}{c}{ UMDLCC } & \multicolumn{2}{c}{ GLMLCC } & \multirow{2}{*}{ Significance level } \\
\cline { 2 - 5 } & Mean & SD & Mean & SD & \\
\hline Between LCCs & $4.15 \times 10^{8}$ & $1.1 \times 10^{8}$ & $1.76 \times 10^{8}$ & $0.5 \times 10^{8}$ & \multirow{2}{*}{$t_{13}=12.6 p<0.0001$} \\
Within LCCs & $4.38 \times 10^{4}$ & $1.1 \times 10^{4}$ & $7.71 \times 10^{4}$ & $2.3 \times 10^{4}$ & $t_{13}=9.6 p<0.0001$ \\
\hline
\end{tabular}

Table 2. Average LNS ( $\mathrm{Mg} \mathrm{C} \mathrm{m}^{-2} \mathrm{yr}^{-1}$ ) in the Burdekin Dry Tropics (BDT) region for all six combinations of degraded and non-degraded LNS conditions and three interannual LNS trends - no trend and positive and negative trends. The percentage of BDT area in each land condition is shown in parentheses.

\begin{tabular}{llll}
\hline \multirow{2}{*}{ Trend category } & \multicolumn{3}{c}{ Degradation condition $\left(\mathrm{MgC} \mathrm{m}^{-2} \mathrm{yr}^{-1}\right)$} \\
\cline { 2 - 4 } & Non-degraded LNS & Degraded LNS & Average \\
\hline No LNS trend & $-1.70(65.3 \%)$ & $-3.85(14.1 \%)$ & $-2.08(79.4 \%)$ \\
Positive LNS trend & $-1.90(10.0 \%)$ & $-3.95(3.6 \%)$ & $-2.44(13.6 \%)$ \\
Negative LNS trend & $-1.48(5.0 \%)$ & $-4.14(2.0 \%)$ & $-2.24(7.0 \%)$ \\
Average & $-1.71(80.3 \%)$ & $-3.90(19.7 \%)$ & $-2.14(100 \%)$ \\
\hline
\end{tabular}

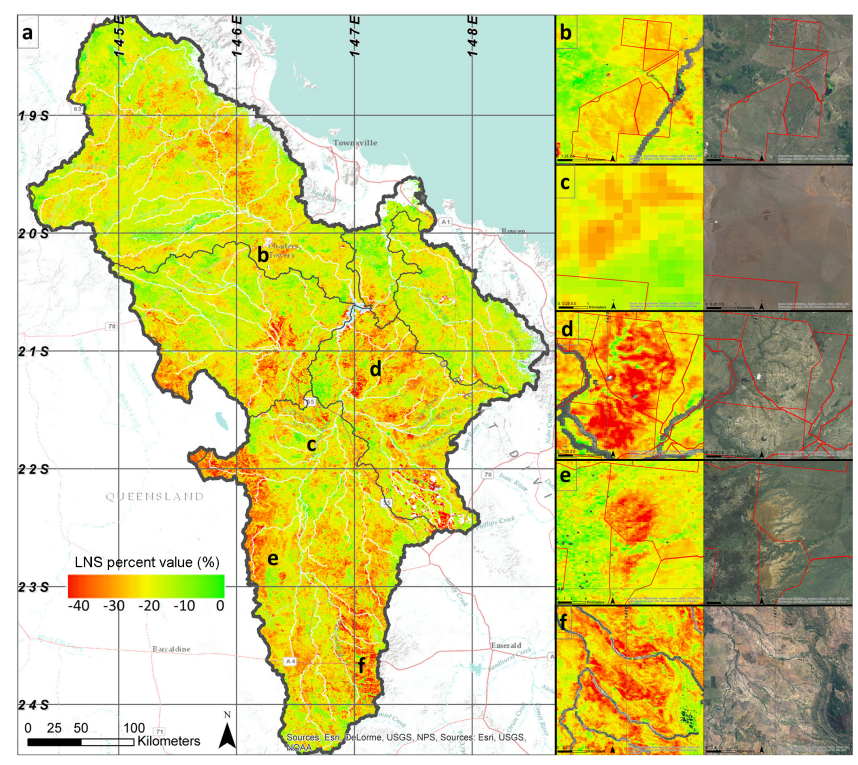

Figure 5. Local net production scaling (LNS) in the Burdekin Dry Tropics (BDT) (a) and enlargements of the areas indicated in (a): (b) high and low LNS values on either side of a station boundary, (c) variation within a single station showing gradients from low to high, (d) low LNS in eroded drainage area, (e) hillslope erosion resulting in bare surface with little to no vegetation cover, and (f) area of tree removal with visible erosion and reduced cover. Black lines are the boundaries of river basins and red lines are station boundaries.

\subsection{Spatial variation in LNS}

The extent of "degraded" and "non-degraded" areas varied between the six major river basins (Tables 4 and 5). Two of these, Belyando and Suttor, comprised $67 \%$ of all "degraded" areas in the entire BDT, while the Bowen Broken Bogie had the lowest (2\%) (Table 4). Despite being the first and third largest basins in the BDT ("degraded" plus "non-degraded" pixels) the Upper Burdekin and Cape Campaspe had only the third and fourth most "degraded" pixels (Table 4), respectively. However, "non-degraded" area decreased with decreasing size of each river basin (Table 5).

The severity of reductions in NPP, indicated by the average LNS, varied surprisingly little between river basins (Tables 4 and 5). The most severely degraded were in the Lower Burdekin, Bowen Broken Bogie, and Upper Burdekin (Table 4). The Upper Burdekin also had the most severe reductions of non-degraded pixels (Table 5). The Belyando and Cape Campaspe had the least severe reductions in NPP of degraded and non-degraded pixels, respectively. The average LNS and its percentage of the reference NPP for degraded and nondegraded pixels, however, were all within 1 standard deviation, suggesting that the reductions in NPP for each river basin did not differ substantially.

Among degraded areas there was evidence of managed grazing, including abrupt differences in LNS along station boundaries (Fig. 5b), but there were also gradients of LNS within a single station (Fig. 5c), and others with low LNS spread across multiple boundaries (Fig. 5d). Other areas with evidence of management included forest clearing (Fig. 5e) near station boundaries. There were also locations classified 
Table 3. Area and percentage of Burdekin Dry Tropics in each LNS range.

\begin{tabular}{lrll}
\hline Degradation condition & LNS range & $\begin{array}{l}\text { Total area }\left(\mathrm{km}^{2}\right) \\
\text { and percent of BDT }\end{array}$ & $\begin{array}{l}\text { Total reduction in } \\
\text { NPP }(\mathrm{GgC})\end{array}$ \\
\hline Non-degraded & 0 to $-9 \%$ & $1.12 \times 10^{6}(15.8 \%)$ & $-1.9(80.3 \%)$ \\
& -10 to $-19 \%$ & $2.40 \times 10^{6}(33.9 \%)$ & \\
& -20 to $-29 \%$ & $2.10 \times 10^{6}(29.6 \%)$ & \\
Degraded & -30 to $-39 \%$ & $0.96 \times 10^{6}(13.6 \%)$ & $-1.1(19.7 \%)$ \\
& -40 to $-49 \%$ & $0.35 \times 10^{6}(5.0 \%)$ & \\
& -50 to $-59 \%$ & $0.10 \times 10^{6}(1.5 \%)$ & \\
& -60 to $-69 \%$ & $0.03 \times 10^{6}(0.4 \%)$ & \\
& -70 to $-79 \%$ & $0.01 \times 10^{6}(0.1 \%)$ & \\
& $<-80$ & $0.00 \times 10^{6}(<0.0 \%)$ & \\
\hline
\end{tabular}

Table 4. Degraded LNS class. Area, severity, and variation in LNS and LNS percent. SD - standard deviation.

\begin{tabular}{llll}
\hline $\begin{array}{l}\text { River basin (in decreasing } \\
\text { order of area) }\end{array}$ & $\begin{array}{l}\text { Total area in } \mathrm{km}^{2} \text { and } \\
\text { percent of the class }\end{array}$ & $\begin{array}{l}\text { Average LNS in } \\
\mathrm{gC} \mathrm{m}^{-2} \mathrm{yr}^{-1}\end{array}$ & $\begin{array}{l}\text { Average LNS as a } \\
\text { percentage of reference } \\
\text { NPP }\end{array}$ \\
\hline Upper Burdekin & $2.28 \times 10^{5}(16 \%)$ & $-225.3(\mathrm{SD}=42.8)$ & $-36 \%(\mathrm{SD}=6)$ \\
Belyando & $6.60 \times 10^{5}(45 \%)$ & $-200.2(\mathrm{SD}=47.5)$ & $-40 \%(\mathrm{SD}=8)$ \\
Cape Campaspe & $2.05 \times 10^{5}(14 \%)$ & $-205.3(\mathrm{SD}=45.6)$ & $-39 \%(\mathrm{SD}=9)$ \\
Suttor & $3.17 \times 10^{5}(22 \%)$ & $-215.3(\mathrm{SD}=52.0)$ & $-40 \%(\mathrm{SD}=9)$ \\
Bowen Broken Bogie & $0.33 \times 10^{5}(2 \%)$ & $-225.7(\mathrm{SD}=45.7)$ & $-36 \%(\mathrm{SD}=7)$ \\
Lower Burdekin & $0.25 \times 10^{5}(2 \%)$ & $-226.7(\mathrm{SD}=55.1)$ & $-38 \%(\mathrm{SD}=8)$ \\
Entire BDT region & $14.79 \times 10^{5}(100 \%)$ & $-209.1(\mathrm{SD}=48.7)$ & $-39 \%(\mathrm{SD}=8)$ \\
\hline
\end{tabular}

as degraded, with little evidence of direct grazing management such as between the drainage lines of streams (Fig. 5f).

\subsection{Interannual trends in LNS}

Across the entire BDT there was substantial interannual variation in LNS, particularly in areas with low values (Fig. 6a). In years with high rainfall (e.g., 2000, 2008, 2009, and 2011) compared with low rainfall (e.g., 2003, 2005, and 2013), there were fewer pixels with low LNS, but the severity of reductions was greater. In areas with little topographic variation, such as the central BDT, there was more spatial variation in low values between years. Positive trends were found predominately in the western and southern Upper Burdekin and southern Belyando basins. Negative trends were most common in the northern Belyando, central Upper Burdekin, and southern Suttor river basins. In total, $79.4 \%$ of the BDT had no significant trend in LNS.

The magnitudes of negative and positive interannual trends in LNS varied substantially between river basins (Fig. 6b, Tables 6 and 7). The Suttor had by far the lowest negative trends (but the largest standard deviation; Table 6). The Upper Burdekin and Cape Campaspe had the least negative trends (Table 6). Positive trends were highest in the Bowen Broken Bogie and lowest in the Belyando (Table 7).
Some patches of positive and negative LNS trends were found in large areas that spanned multiple river basins (Fig. 6b). These may have been a result of environmental conditions (e.g., low rainfall, soil properties) in some combination other than that used to create the LCCs, or of a single variable not used in the classification that crosses the LCC boundaries, for example more friable soils.

There were strong contrasts in the average LNS of the negative and positive trend classes between river basins (Tables 6 and 7). The average LNS of negative trends in the Suttor was nearly twice that of the Upper Burdekin. The Suttor River basin had most severe LNS reductions in the negative trend class (Table 6). On average, for negative trends, the Bowen Broken Bogie, Upper Burdekin, and Lower Burdekin had the least severe reductions in NPP, while the most severe were in the southern river basins: Belyando, Cape Campaspe, and Suttor (Table 6). Surprisingly, the Belyando had less severe reductions in NPP in areas with negative trends (Table 6) than in areas with positive trends (Tables 7). In the Belyando, the percent LNS for positive trends were less than $-30 \%$, suggesting that numerous low LNS values were found among positive trends. 
Table 5. Non-degraded LNS class. Area, severity, and variation in LNS and LNS percent. SD - standard deviation.

\begin{tabular}{llll}
\hline $\begin{array}{l}\text { River basin (in decreasing } \\
\text { order of area) }\end{array}$ & $\begin{array}{l}\text { Total area in } \mathrm{km}^{2} \text { and } \\
\text { percent of the class }\end{array}$ & $\begin{array}{l}\text { Average LNS in } \\
\mathrm{gC} \mathrm{m}^{-2} \mathrm{yr}^{-1}\end{array}$ & $\begin{array}{l}\text { Average LNS as a } \\
\text { percentage of reference } \\
\text { NPP }\end{array}$ \\
\hline Upper Burdekin & $20.34 \times 10^{5}(34 \%)$ & $-105.3(\mathrm{SD}=45.0)$ & $-17 \%(\mathrm{SD}=7)$ \\
Belyando & $14.15 \times 10^{5}(24 \%)$ & $-92.2(\mathrm{SD}=39.2)$ & $-18 \%(\mathrm{SD}=7)$ \\
Cape Campaspe & $9.74 \times 10^{5}(16 \%)$ & $-88.3(\mathrm{SD}=41.2)$ & $-16 \%(\mathrm{SD}=8)$ \\
Suttor & $7.57 \times 10^{5}(13 \%)$ & $-97.4(\mathrm{SD}=41.2)$ & $-18 \%(\mathrm{SD}=8)$ \\
Bowen Broken Bogie & $6.01 \times 10^{5}(10 \%)$ & $-99.6(\mathrm{SD}=49.8)$ & $-15 \%(\mathrm{SD}=7)$ \\
Lower Burdekin & $2.03 \times 10^{5}(3 \%)$ & $-95.4(\mathrm{SD}=49.5)$ & $-15 \%(\mathrm{SD}=8)$ \\
Entire BDT region & $59.83 \times 10^{5}(100 \%)$ & $-97.5(\mathrm{SD}=43.9)$ & $-17 \%(\mathrm{SD}=7)$ \\
\hline
\end{tabular}

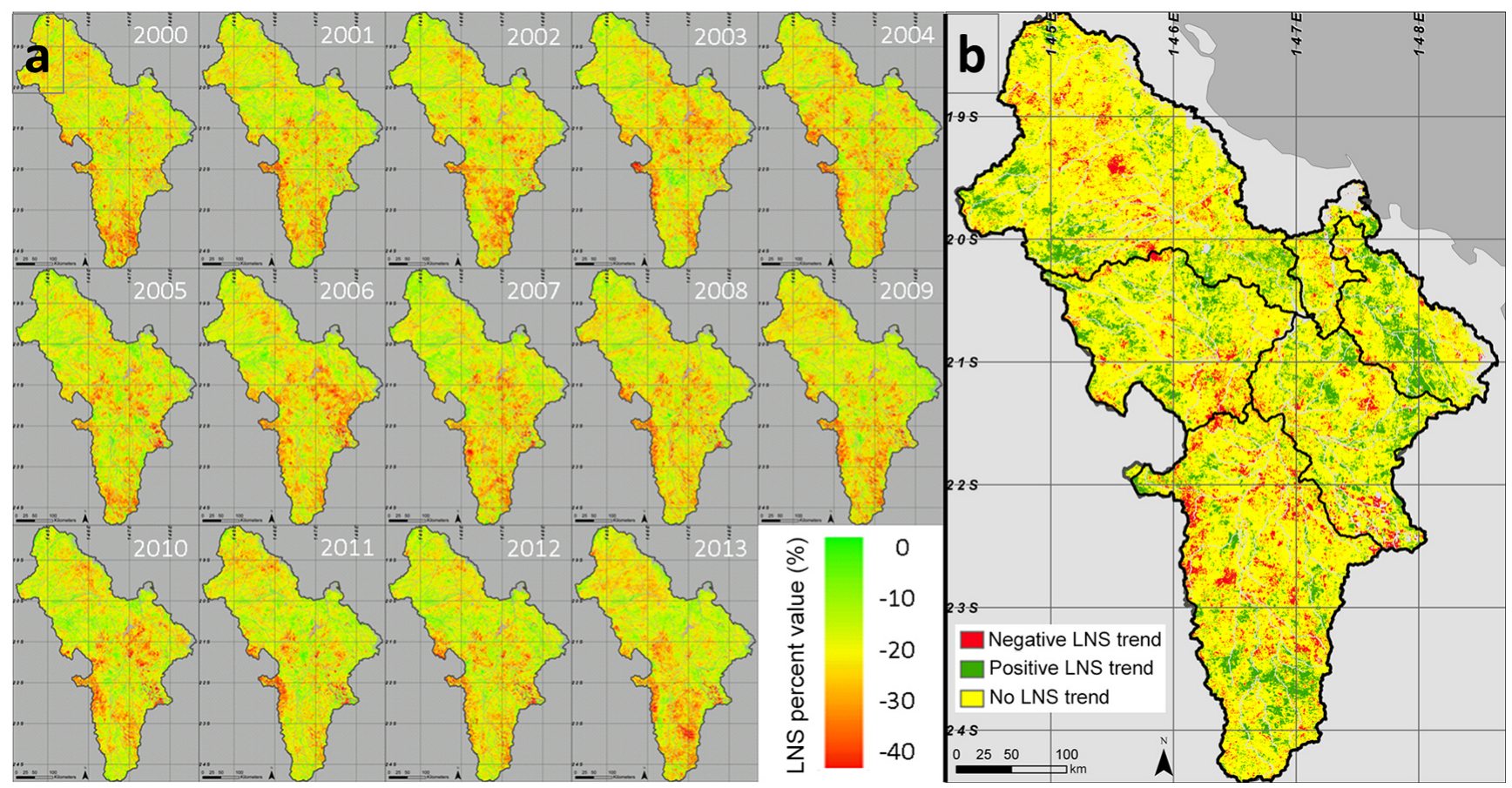

Figure 6. Time series of maps of the Burdekin Dry Tropics from 2000 to 2013 showing (a) annual LNS percent values from 2000 to 2013 and (b) interannual trends in LNS classified into negative, positive, and no LNS trend.

\subsection{Comparisons of LNS and environmental characteristics}

For the entire BDT, the overall spatial distribution of annual hillslope erosion was strongly correlated $(k=0.7)$ with LNS. Other environmental variables indicative of degradation (gully density, rainfall erosivity, and sediment load) were also high overall $(k=0.6)$. For individual pixels, maps of correlation revealed strong regional differences (Fig. 7). The Suttor had the greatest spatial agreement between LNS and each environmental variable, while the Bowen Broken Bogie had the least. Strong agreement between annual hillslope erosion and LNS occurred throughout the BDT (Fig. 7a), particularly in the central Upper Burdekin, Cape Campaspe, Suttor, and Belyando. The spatial agreement between LNS and gully density (Fig. 7b) was largely similar to that of LNS and hillslope erosion except for the presence of large clusters of low kappa values in the northern basins. The spatial pattern in kappa values for LNS and rainfall erosivity (Fig. 7c) and sediment load (Fig. 7d) resembled rainfall gradients in the region, northeast to southwest.

VAST classes were generally correlated with LNS (Table 8). The average LNS declined with increasing human modification. "Removed" and "bare" had the lowest average LNS of any VAST class. The only negative trend was in the "bare" class, presumably an indication that a small amount of vegetation was present, while "removed" had the largest positive trend. Interannual trends in LNS further differentiated the two classes; "bare" had the only negative trend, while "removed" had the largest positive trend, which may be a re- 
Table 6. Negative trends in area, interannual rate, and severity of LNS for river basins of the Burdekin Dry Tropics. SD - standard deviation.

\begin{tabular}{llll}
\hline $\begin{array}{l}\text { River basin (in decreasing } \\
\text { order of area) }\end{array}$ & $\begin{array}{l}\text { Total area in } \mathrm{km}^{2} \\
\text { and percentage of those } \\
\text { areas with negative trends }\end{array}$ & $\begin{array}{l}\text { Average trend in } \\
\mathrm{gC} \mathrm{m}^{-2} \mathrm{yr}^{-1}\end{array}$ & $\begin{array}{l}\text { Average LNS in } \\
\mathrm{gC} \mathrm{m}^{-2} \mathrm{yr}^{-1} \text { and } \\
\text { as a percentage of } \\
\text { reference NPP }\end{array}$ \\
\hline Upper Burdekin & $1.26 \times 10^{5}(24 \%)$ & $-7.3(\mathrm{SD}=2.8)$ & $-102.0(-16 \%)$ \\
Belyando & $2.10 \times 10^{5}(40 \%)$ & $-8.4(\mathrm{SD}=3.3)$ & $-134.0(-27 \%)$ \\
Cape Campaspe & $0.71 \times 10^{5}(14 \%)$ & $-7.5(\mathrm{SD}=2.6)$ & $-131.7(-24 \%)$ \\
Suttor & $0.77 \times 10^{5}(15 \%)$ & $-13.8(\mathrm{SD}=10.0)$ & $-184.2(-34 \%)$ \\
Bowen Broken Bogie & $0.22 \times 10^{5}(4 \%)$ & $-9.7(\mathrm{SD}=6.0)$ & $-95.0(-14 \%)$ \\
Lower Burdekin & $0.15 \times 10^{5}(3 \%)$ & $-9.5(\mathrm{SD}=5.6)$ & $-116.0(-17 \%)$ \\
Entire BDT region & $5.21 \times 10^{5}(100 \%)$ & $-8.9(\mathrm{SD}=5.4)$ & $-120.5(-25 \%)$ \\
\hline
\end{tabular}

Table 7. Positive trends in area, interannual rate, and severity of LNS for river basin of the Burdekin Dry Tropics. SD - standard deviation.

\begin{tabular}{llll}
\hline $\begin{array}{l}\text { River basin (in decreasing } \\
\text { order of area) }\end{array}$ & $\begin{array}{l}\text { Total area in } \mathrm{km}^{2} \\
\text { and percentage of those } \\
\text { areas with positive trends }\end{array}$ & $\begin{array}{l}\text { Average trend in } \\
\mathrm{gC} \mathrm{m}^{-2} \mathrm{yr}^{-1}\end{array}$ & $\begin{array}{l}\text { Average LNS in } \\
\mathrm{gC} \mathrm{m}^{-2} \mathrm{yr}^{-1} \text { and } \\
\text { as a percentage of } \\
\text { reference NPP }\end{array}$ \\
\hline Upper Burdekin & $2.70 \times 10^{5}(27 \%)$ & $7.6(\mathrm{SD}=2.7)$ & $-124.5(-20 \%)$ \\
Belyando & $2.50 \times 10^{5}(25 \%)$ & $6.8(\mathrm{SD}=3.3)$ & $-151.1(-31 \%)$ \\
Cape Campaspe & $1.53 \times 10^{5}(15 \%)$ & $7.3(\mathrm{SD}=3.0)$ & $-113.4(-21 \%)$ \\
Suttor & $1.67 \times 10^{5}(16 \%)$ & $8.7(\mathrm{SD}=3.7)$ & $-139.6(-26 \%)$ \\
Bowen Broken Bogie & $1.46 \times 10^{5}(14 \%)$ & $10.1(\mathrm{SD}=3.6)$ & $-118.4(-19 \%)$ \\
Lower Burdekin & $0.31 \times 10^{5}(3 \%)$ & $8.6(\mathrm{SD}=3.4)$ & $-117.2(-18 \%)$ \\
Entire BDT region & $10.16 \times 10^{5}(100 \%)$ & $7.9(\mathrm{SD}=3.4)$ & $-130.7(-23 \%)$ \\
\hline
\end{tabular}

sult of the strongest regrowth from the lowest starting value of all the classes.

\section{Discussion}

\subsection{Land capability classification (LCC) and local NPP scaling (LNS)}

The basis of selection of the reference NPP and detection of anthropogenic reductions in LNS is the classification of the landscape into uniform units (LCCs) with respect to the environmental factors that affect NPP. The procedure was generally successful in creation of classes of environmentally uniform pixels, differing only in the long-term degree of degradation. The same reference sites were frequently selected in multiple, sometimes consecutive, years for the 14 years included in the study and therefore potentially for a longer term. This indicates that degradation, as detected with LNS, corresponded to sites that were persistently below the potential. This emphasized that these sites were not simply subject to some short-term environmental deficiency, such as a single year with spatially patchy lower rainfall. The value of incorporating interannual variation of precipitation in the classification rather than a climatological average is illustrated by the comparison of GLM. UMDLCC proved better able to minimize within-LCC variance while also maximizing the between-LCC variance (Table 1, Fig. 4a and b). The large numbers of UMD reference sites that fell in the VAST "residual" class and the larger reductions in NPP in VAST classes with higher levels of human modification offer further evidence of the reliability of the UMDLCC classification (Table 8). Furthermore, the spatial coincidence of differences in management with differences in LNS found by visual inspection of high resolution imagery suggests that the procedure was able to distinguish regional, anthropogenic land degradation from natural variation in environmental factors.

Nevertheless, undetected errors may arise in the classification process, some of which are noted in the Methods section. Changes in land cover during the study period are unlikely to have caused errors since the rates of pasture clearing decreased dramatically throughout the Burdekin region from 1988 to 2002 and remained relatively low during the study period (2000 to 2012; DSITIA, 2014). A more fundamental problem might arise because the classification procedure did not allow for any interactions between environmental factors in different parts of the study area. A possible example of this from the BDT is the location of the largest spatial variations in LNS and its interannual trends near the coastline (e.g., 
Table 8. VAST class comparison with interannual trends in LNS and average LNS. SD - standard deviation.

\begin{tabular}{llll}
\hline VAST classes & $\begin{array}{l}\text { Average trend in } \\
\mathrm{gC} \mathrm{m}^{-2} \mathrm{yr}^{-1}\end{array}$ & $\begin{array}{l}\text { Average LNS in } \\
\mathrm{gC} \mathrm{m}^{-2} \mathrm{yr}^{-1}\end{array}$ & $\begin{array}{l}\text { Average LNS as a } \\
\text { percentage of reference } \\
\text { NPP }\end{array}$ \\
\hline 0-"Residual" & $0.3(\mathrm{SD}=4.7)$ & $-110.2(\mathrm{SD}=63.7)$ & $-19.7 \%(\mathrm{SD}=11.1)$ \\
1-"Modified" & $1.0(\mathrm{SD}=4.8)$ & $-110.2(\mathrm{SD}=61.5)$ & $-19.4 \%(\mathrm{SD}=10.5)$ \\
2-"Transformed" & $1.1(\mathrm{SD}=5.1)$ & $-115.2(\mathrm{SD}=62.6)$ & $-21.6 \%(\mathrm{SD}=11.7)$ \\
3-"Replaced" & $0.6(\mathrm{SD}=6.1)$ & $-123.6(\mathrm{SD}=66.1)$ & $-24.9 \%(\mathrm{SD}=12.6)$ \\
4-"Removed" & $1.5(\mathrm{SD}=5.3)$ & $-171.5(\mathrm{SD}=98.2)$ & $-32.7 \%(\mathrm{SD}=17.7)$ \\
5-"Bare" & $-0.9(\mathrm{SD}=7.3)$ & $-130.2(\mathrm{SD}=78.6)$ & $-23.9 \%(\mathrm{SD}=14.5)$ \\
\hline
\end{tabular}

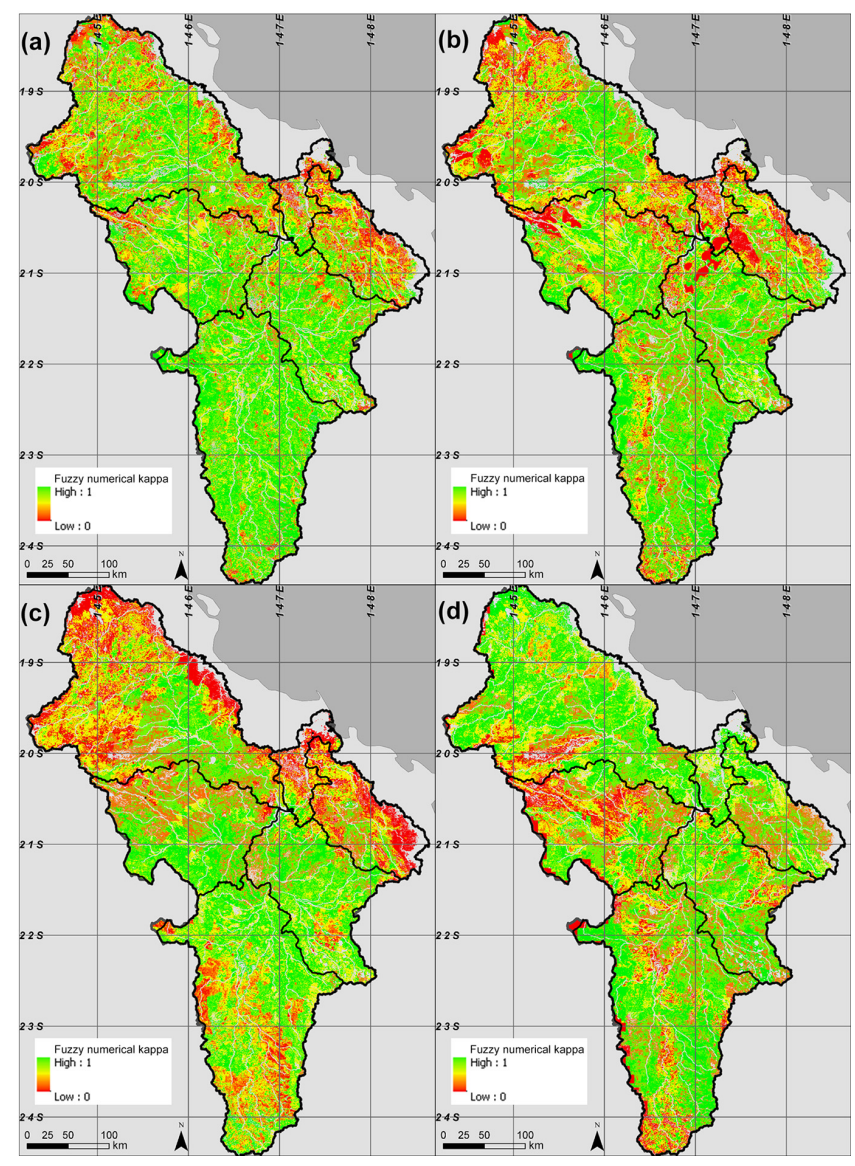

Figure 7. Similarities between (a) annual hillslope erosion, (b) gully density, (c) rainfall erosivity, and (d) sediment load and percentage LNS as indicated by fuzzy numeric kappa.

Lower Burdekin and Bowen Broken Bogie), where rainfall is highest. This is an example of a drawback of statistical classification which can only account for additive effects of the environment, whereas, for example, moisture availability can alter the response of production to management (Ibrahim et al., 2015), possibly nonlinearly. This points to an advantage of replacing the statistical derivation of LCCs with a processbased model that can convolve the environmental factors in realistic mechanisms. Such a model run in "potential" mode, which is without any anthropogenic effects, could create a reference NPP for each pixel. At the present time, however, the environmental variables and parameters needed for a useful process model are only rarely available.

\subsection{Extent of degradation of NPP in the BDT}

Across the entire BDT region, from 2000 to 2013, the average annual reduction in NPP below the reference was $2.14 \mathrm{MgC} \mathrm{m}^{-2} \mathrm{yr}^{-1}$ (Table 2). The average LNS in the non-degraded class (arbitrarily set at LNS between 0 and $-29 \%$ ) was $-97.5 \mathrm{gC} \mathrm{m}^{-2} \mathrm{yr}^{-1}$ and the degraded class (LNS $<30 \%)-209.1 \mathrm{gC} \mathrm{m}^{-2} \mathrm{yr}^{-1}$ (Tables 4 and 5). However, owing to the greater area of "non-degraded" land in the entire BDT $(80.3 \%)$ compared to the "degraded" class $(19.7 \%)$ (Table 2), the total NPP reduction in non-degraded areas was actually greater. Reductions in NPP, as indicated by low LNS, affect the carbon pool in several ways: by reduced rates of sequestration (Dregne, 1983); by reduction in biomass of live and dead vegetation; by loss of soil organic matter (Burke et al., 1995; Smith et al., 2012; Su et al., 2005); or by a shortened growing season, for example among introduced, less-adapted, pasture species (Falge et al., 2002a, b). The large reduction in NPP found here is in agreement with reports of episodes of widespread land degradation occurring in the BDT (McKeon et al., 2004; Smith et al., 2007; Stone et al., 2007).

Overall, positive temporal trends in LNS were twice as common as negative trends (Tables 6 and 7). The "nondegraded with no trend" class had the largest total area $(65.3 \%)$. This class was widespread in every river basin, indicating that most of the BDT region was not affected by severe degradation. In other areas, for example in Belyando and Bowen Broken Bogie, the average LNS of "degraded with positive trends" areas suggests that significant areas were recovering from earlier degradation (Table 7). Nevertheless, some areas were degrading between 2000 and 2013, and in some their negative trends intensified through the study period, as indicated by the extent of the "degraded with negative trends" class (Table 2). Areas classified as "degraded with negative trends" occupied $24.7 \%$ of the entire BDT- 
candidate areas for actions to reverse or at least arrest the trend. There were a few instances of "degraded with no trends", a possible indicator sites in a state of long-term, maybe permanent, irreversible degradation or approaching this state. Permanent degradation is a serious condition since it is generally reversible only with intensive remediation (Prince, 2002; Reynolds et al., 2007), which often costs more than the value of the restored land; however, there were a few areas of "degraded with positive trends" which may be examples of land that has been rehabilitated.

\subsection{Anthropogenic and environmental degradation}

While substantial reductions in NPP were found across the BDT region as whole, there was considerable variation between river basins. The link between anthropogenic disturbance and rates of degradation (detected here by low LNS) has been noted by Hill et al. (2005) and Kairis et al. (2015) and specifically in the BDT by McKeon et al. (2009). Independent evidence for anthropogenesis presented here includes correlation with the VAST map which, although not a map of vegetation degradation, does distinguish varying degrees of human-related modification of native vegetation (Thackway and Lesslie, 2005). The good agreement of ranks of average LNS and the VAST classes (Table 8) is evidence that LNS was able to separate human-related degradation from natural variation, at least up to the end of the period of time used for the VAST map (i.e., 2011). In addition, there was qualitative evidence from visual inspection of high resolution remotely sensed imagery, such as abrupt differences across station boundaries (e.g., Fig. 5b, c) and coincidences of visible disturbance around livestock water points. The relationship between degradation, accelerated rates of erosion, and reduced vegetation cover is well known (Lal, 2001) and erosion is the most widespread and recognizable characteristics of land degradation (Ravi et al., 2010), also a primary impact on loss of soil carbon (Rajan et al., 2010). In the present study, there was a strong overall correlation of average LNS with hillslope erosion and gully density (Fig. 7). In the BDT, others have linked erosion with poor grazing management (Bartley et al., 2006) and unsustainable agricultural production (Montgomery, 2007).

Assigning causal relationships to land degradation and natural or anthropogenic factors is difficult due to the close coupling between humans and their environment (Reynolds et al., 2007). The LNS procedure offers one approach that attempts to isolate actual degradation of NPP from less favorable environmental conditions. However, without additional data on land usage, such as livestock numbers and management practices, the causes of the reductions by human-related activities are hard to determine (Bastin et al., 2012). The most commonly cited management practices to reduce degradation are reduction in domestic livestock, reduction in feral herbivores, removal of watering points (Bastin et al., 2012; Fensham and Fairfax, 2008; Silcock and Fensham, 2013), fal- lowing (Bastin et al., 1993, 2012), or encouraging vegetation that is particularly resistant to overgrazing or able to recover quickly after intense grazing (Bastin et al., 2012; McKeon et al., 2004; Smith et al., 2007). Additional data are needed to interpret low LNS, particularly with field observation.

Given the extremely large areas of provincial, national, regional, and global degradation that are frequently stated (Bai et al., 2008; Bridges and Oldeman, 1999; Kassas, 1995; Oldeman, 1994; UNEP, 1997; Zika and Erb, 2009) and the far-reaching effects of degradation on human livelihoods (Adeel, 2008; UNCCD, 1994), rigorous, quantitative, and objective measurements are urgently needed. While reduction of NPP is a single type of degradation, it is a quantitative measure of the outcome of most forms of degradation relevant to human needs - but not all (e.g., loss of palatable species with no change in NPP; Asner and Heidebrecht, 2005). The widespread occurrence of degradation and its anthropogenic causes and effects require measurements having the large-area coverage and high spatial resolution provided by remote sensing, despite their limitations. LNS is founded on the concept of comparison of the actual conditions with their potential. As noted, there are several weaknesses in the technique that may affect the validity of the results; nevertheless, the fundamental concept of reduction from an explicit standard remains. There also remains a need for improvements in detection of appropriate reference standards, either by local scaling as in LNS or by some other method.

The objectives of the many initiatives to arrest and remediate degradation have been summarized in the concept of zero net land degradation (ZNLD) (Stavi and Lal, 2015). ZNLD seeks to slow current rates of degradation such that the rates of land rehabilitation are, at the very least, equivalent to rates of deterioration (Lal et al., 2012), locally or elsewhere. Achievement of ZNLD depends on comprehensive monitoring to identify land states and trends of degradation. The study presented here used one approach to such regional assessment. While the feasibility of global land degradation neutrality has been debated (Grainger, 2015), the BDT is an example of a region that has seen a reversal of an overall trend toward degradation in productivity.

Edited by: Richard Conant

Reviewed by: B. K. Wylie and one anonymous referee

\section{References}

Accatino, F., De Michele, C., Vezzoli, R., Donzelli, D., and Scholes, R. J.: Tree-grass co-existence in savanna: Interactions of rain and fire, J. Theor. Biol., 267, 235-242, 2010.

ACLEP: National soil data, (ACLEP), National Committee on Soil and Terrain (NCST), Canberra, Australia, 2011.

Adeel, Z.: Findings of the Global Desertification Assessment by the Millennium Ecosystem Assessment - A Perspective for Better Managing Scientific Knowledge, in: Future of Drylands, edited 
by: Lee, C. and Schaaf, T., Springer, P.O. Box 17, 3300 Dordrecht, the Netherlands, 2008.

Asner, G. P. and Heidebrecht, K. B.: Desertification alters regional ecosystem-climate interactions, Glob. Change Biol., 11, 182194, 2005.

Bai, Z. G., Dent, D. L., Olsson, L., and Schaepman, M. E.: Proxy global assessment of land degradation, Soil Use Manage., 24, 223-234, 2008.

Bartley, R., Roth, C. H., Ludwig, J., McJannet, D., Liedloff, A., Corfield, J., Hawdon, A., and Abbott, B.: Runoff and erosion from Australia's tropical semi-arid rangelands: influence of ground cover for differing space and time scales, Hydrol. Process., 20, 3317-3333, 2006.

Bastin, G., Scarth, P., Chewings, V., Sparrow, A., Denham, R., Schmidt, M., O'Reagain, P., Shepherd, R., and Abbott, B.: Separating grazing and rainfall effects at regional scale using remote sensing imagery: A dynamic reference-cover method, Remote Sens. Environ., 121, 443-457, 2012.

Bastin, G. N., Pickup, G., Chewings, V. H., and Pearce, G.: Land degradation assessment in central Australia using grazing gradient method, Rangeland J., 15, 190-216, 1993.

Beringer, J., Hutley, L. B., Tapper, N. J., and Cernusak, L. A.: Savanna fires and their impact on net ecosystem productivity in North Australia, Glob. Change Biol., 13, 990-1004, 2007.

Boer, M. and Smith, M. S.: A plant functional approach to the prediction of changes in Australian rangeland vegetation under grazing and fire, J. Veg. Sci., 14, 333-344, 2003.

Boer, M. M. and Puigdefabregas, J.: Assessment of dryland condition using spatial anomalies of vegetation index values, Int. J. Remote Sens., 26, 4045-4065, 2005.

Bridges, E. M. and Oldeman, L. R.: Global assessment of humaninduced soil degradation, Arid Soil Res. Rehab., 13, 319-325, 1999.

Budde, M. E., Tappan, G., Rowland, J., Lewis, J., and Tieszen, L. L.: Assessing land cover performance in Senegal, West Africa using 1-km integrated NDVI and local variance analysis, J. Arid Environ., 59, 481-498, 2004.

Bui, E. N., Hancock, G. J., and Wilkinson, S. N.: “Tolerable” hillslope soil erosion rates in Australia: Linking science and policy, Agr. Ecosyst. Environ., 144, 136-149, 2011.

Burke, I. C., Lauenroth, W. K., and Coffin, D. P.: Soil OrganicMatter Recovery In Semiarid Grasslands - Implications For The Conservation Reserve Program, Ecol. Appl., 5, 793-801, 1995.

Cohen, J.: A coefficient of agreement for nominal scales, Educ. Psychol. Meas., 20, 37-46, 1960.

Danaher, T., Armston, J., and Collett, L.: A regression model approach for mapping woody foliage projective cover using landsat imagery in Queensland, Australia, Igarss 2004: Ieee International Geoscience and Remote Sensing Symposium Proceedings, Vols. 1-7, Science for Society: Exploring and Managing a Changing Planet, 523-527, 2004.

DPI\&F: Stocktake: Balancing supply and demand, Department of Primary Industries and Fisheries, www.stocktakeplus.com.au (last access: 1 September 2015), 2004.

Dregne, H. E.: Desertification of arid lands, in: Physics of desertification, edited by: El-Baz, F. and Hassan, M. H. A., Harwood Academic Publishers, Chur, Switzerland, New York, 1983.

Dregne, H. E.: Erosion and Soil Productivity in Australia and NewZealand, Land Degrad. Rehabil., 6, 71-78, 1995.
DSITIA: Land cover change in Queensland 2011-12: a Statewide Landcover and Trees Study (SLATS) Report, Department of Science, Information Technology, Innovation and the Arts, Brisbane, Department of Science, Information Technology, Innovation and the Arts, 2014.

Falge, E., Baldocchi, D., Tenhunen, J., Aubinet, M., Bakwin, P., Berbigier, P., Bernhofer, C., Burba, G., Clement, R., Davis, K. J., Elbers, J. A., Goldstein, A. H., Grelle, A., Granier, A., Guomundsson, J., Hollinger, D., Kowalski, A. S., Katul, G., Law, B. E., Malhi, Y., Meyers, T., Monson, R. K., Munger, J. W., Oechel, W., Paw, K. T., Pilegaard, K., Rannik, U., Rebmann, C., Suyker, A., Valentini, R., Wilson, K., and Wofsy, S.: Seasonality of ecosystem respiration and gross primary production as derived from FLUXNET measurements, Agr. Forest Meteorol., 113, 5374, 2002a.

Falge, E., Tenhunen, J., Baldocchi, D., Aubinet, M., Bakwin, P., Berbigier, P., Bernhofer, C., Bonnefond, J. M., Burba, G., Clement, R., Davis, K. J., Elbers, J. A., Falk, M., Goldstein, A. H., Grelle, A., Granier, A., Grunwald, T., Gudmundsson, J., Hollinger, D., Janssens, I. A., Keronen, P., Kowalski, A. S., Katul, G., Law, B. E., Malhi, Y., Meyers, T., Monson, R. K., Moors, E., Munger, J. W., Oechel, W., U, K. T. P., Pilegaard, K., Rannik, U., Rebmann, C., Suyker, A., Thorgeirsson, H., Tirone, G., Turnipseed, A., Wilson, K., and Wofsy, S.: Phase and amplitude of ecosystem carbon release and uptake potentials as derived from FLUXNET measurements, Agr. Forest Meteorol., 113, 7595, 2002b.

Fensham, R. J. and Fairfax, R. J.: Water-remoteness for grazing relief in Australian arid-lands, Biol. Conserv., 141, 1447-1460, 2008.

Gifford, R. M.: Carbon sequestration in Australian grasslands: policy and technical issues, in: Integrated Crop Management Grassland carbon sequestration: management, policy and economics, Proceedings of the Workshop on the role of grassland carbon sequestration in the mitigation of climate change, edited by: Abberton, M., Conant, R., and Batello, C., Food and Agriculture Organization of the United Nations (FAO), Rome, April 2009, 2010.

Gillieson, D., Wallbrink, P., and Cochrane, A.: Vegetation change, erosion risk and land management on the Nullarbor Plain, Australia, Environ. Geol., 28, 145-153, 1996.

Grainger, A.: Is Land Degradation Neutrality feasible in dry areas?, J. Arid Environ., 112, 14-24, 2015.

Hill, M. J., Roxburgh, S. H., Carter, J. O., and McKeon, G. M.: Vegetation state change and consequent carbon dynamics in savanna woodlands of Australia in response to grazing, drought and fire: a scenario approach using 113 years of synthetic annual fire and grassland growth, Aust. J. Bot., 53, 715-739, 2005.

Hughes, A. O., Prosser, I. P., Stevenson, J., Scott, A., Lu, H., Gallant, J., and Moran, C. J.: Gully Erosion Mapping for the National Land and Water Resources Audit, Technical Report 26/01, CSIRO Land and Water, Canberra, Australia, 2001.

Hutley, L. B., O'Grady, A. P., and Eamus, D.: Evapotranspiration from eucalypt open-forest savanna of northern Australia, Funct. Ecol., 14, 183-194, 2000.

Ibrahim, Y. Z., Balzter, H., Kaduk, J., and Tucker, C. J.: Land Degradation Assessment Using Residual Trend Analysis of GIMMS NDVI3g, Soil Moisture and Rainfall in Sub-Saharan West Africa from 1982 to 2012, Remote Sensing, 7, 5471-5494, 2015. 
Jones, D. A., Wang, W., and Fawcett, R.: High-quality spatial climate data-sets for Australia, Australian Meteorological and Oceanographic Journal, 58, 233-248, 2009.

Kairis, O., Karavitis, C., Salvati, L., Kounalaki, A., and Kosmas, K.: Exploring the Impact of Overgrazing on Soil Erosion and Land Degradation in a Dry Mediterranean Agro-Forest Landscape (Crete, Greece), Arid Land Res. Manag., 29, 360-374, 2015.

Kassas, M.: Desertification - a general-review, J. Arid Environ., 30, 115-128, 1995.

Lal, R.: Soil degradation by erosion, Land Degrad. Dev., 12, 519539, 2001.

Lal, R.: Soil erosion and the global carbon budget, Environ. Int., 29, 437-450, 2003.

Lal, R., Safriel, U., and Boer, B.: Zero Net Land Degradation: A New Sustainable Development Goal for Rio+ 20, UNCCD, 2012.

Lesslie, R., Thackway, R., and Smith, J. A.: national-level Vegetation Assets, States and Transitions (VAST) dataset for Australia (version 2), Bureau of Rural Sciences, Canberra, 2010.

Lu, H., Gallant, J., Prosser, I. P., Moran, C., and Priestley, G.: Prediction of Sheet and Rill Erosion Over the Australian Continent, Incorporating Monthly Soil Loss Distribution, Technical Report 13/01, CSIRO Land and Water, Canberra, Australia, available at: http://www.clw.csiro.au/publications/technical2001/tr13-01 (last access: 10 October 2015), 2001.

McKeon, G., Hall, W., Henry, B., Stone, G., and Watson, I.: Pasture Degradation and Recovery in Australia's Rangelands: Learning from History, Department of Natural Resources Mines and Energy Queensland, Brisbane, 2004.

McKeon, G. M., Stone, G. S., Syktus, J. I., Carter, J. O., Flood, N. R., Ahrens, D. G., Bruget, D. N., Chilcott, C. R., Cobon, D. H., Cowley, R. A., Crimp, S. J., Fraser, G. W., Howden, S. M., Johnston, P. W., Ryan, J. G., Stokes, C. J., and Day, K. A.: Climate change impacts on northern Australian rangeland livestock carrying capacity: a review of issues, Rangeland J., 31, 1-29, 2009.

Mellick, B. and Hanlon, H.: The Burdekin Dry Tropics Natural Resources Management Plan (2005-2010), Burdekin Dry Tropics Board, 2005, 2005.

Montgomery, D. R.: Soil erosion and agricultural sustainability, P. Natl. Acad. Sci. USA, 104, 13268-13272, 2007.

NLWRA: Catchment, river and estuary condition in Australia: a summary of the National Land and Water Resources Audit's Australian catchment, river and estuary assessment 2002, Audit, Natural Heritage Trust (Australia) \& National Land \& Water Resources Audit (Program: Australia), Turner, A.C.T., 2002.

Nusser, S. M. and Goebel, J. J.: The National Resources Inventory: A long-term multi-resource monitoring programme, Environ. Ecol. Stat., 4, 181-204, 1997.

O'Connor, T. G., Haines, L. M., and Snyman, H. A.: Influence of precipitation and species composition on phytomass of a semiarid African grassland, J. Ecol., 89, 850-860, 2001.

Oldeman, L. R.: The global extent of soil degradation, Symposium on Soil Resilience and Sustainable Land Use, including the 2nd Workshop on the Ecological Foundations of Sustainable Agriculture (WEFSA II) Budapest, Hungary, 28 September-2 October 1992, 99-118, 1994.
Petheram, C., McMahon, T. A., and Peel, M. C.: Flow characteristics of rivers in northern Australia: Implications for development, J. Hydrol., 357, 93-111, 2008.

Pickup, G.: Estimating the effects of land degradation and rainfall variation on productivity in rangelands: An approach using remote sensing and models of grazing and herbage dynamics, J. Appl. Ecol., 33, 819-832, 1996.

Pickup, G.: Desertification and climate change - the Australian perspective, Climate Research, 11, 51-63, 1998.

Prince, S. D.: Spatial and temporal scales of measurement of desertification, Global desertification: do humans create deserts?, edited by: Stafford-Smith, M. and Reynolds, J. F., Dahlem University Press, Berlin, 2002.

Prince, S. D.: Mapping desertification in southern Africa, in: Land Change Science: Observing, Monitoring, and Understanding Trajectories of Change on the Earth's Surface, edited by: Gutman, G., Janetos, A., and Justice, C. O., Kluwer, Dordrecht, the Netherlands, 2004.

Prince, S. D.: Where Does Desertification Occur? Mapping Dryland Degradation at Regional to Global Scales, in: The End of Desertification? Disrupting Environmental Change in Drylands, edited by: Behnke, R. and Matimore, M., Springer, 2016.

Prince, S. D., Wessels, K. J., Tucker, C. J., and Nicholson, S. E.: Desertification in the Sahel: a reinterpretation of a reinterpretation, Glob. Change Biol., 13, 1308-1313, 2007.

Prince, S. D., Becker-Reshef, I., and Rishmawi, K.: Detection and mapping of long-term land degradation using local net production scaling: Application to Zimbabwe, Remote Sens. Environ., 113, 1046-1057, 2009.

Rajan, K., Natarajan, A., Kumar, K. S. A., Badrinath, M. S., and Gowda, R. C.: Soil organic carbon - the most reliable indicator for monitoring land degradation by soil erosion, Current Science, 99, 823-827, 2010.

Ravi, S., Breshears, D. D., Huxman, T. E., and D'Odorico, P.: Land degradation in drylands: Interactions among hydrologic-aeolian erosion and vegetation dynamics, Geomorphology, 116, 236245, 2010.

Reynolds, J. F., Stafford Smith, D. M., Lambin, E. F., Turner, B. L., Mortimore, M., Batterbury, S. P. J., Downing, T. E., Dowlatabadi, H., Fernandez, R. J., Herrick, J. E., Huber-Sannwald, E., Jiang, H., Leemans, R., Lynam, T., Maestre, F. T., Ayarza, M., and Walker, B.: Global desertification: Building a science for dryland development, Science, 316, 847-851, 2007.

Running, S. W., Nemani, R. R., Heinsch, F. A., Zhao, M. S., Reeves, M., and Hashimoto, H.: A continuous satellite-derived measure of global terrestrial primary production, Bioscience, 54, 547560, 2004.

Rustomji, P., Bennett, N., and Chiew, F.: Flood variability east of Australia's Great Dividing Range, J. Hydrol., 374, 196-208, 2009.

Safriel, U.: The Assessment of Global Trends in Land Degradation, Climate Land Degradation, 2007, 1-38, 2007.

Safriel, U. and Adeel, Z.: Dryland Systems, Millennium Ecosystem Assessment: Ecosystems and Human Well-being: Current State and Trends, Washington, DC, 638, 2005.

Silcock, J. L. and Fensham, R. J.: Arid vegetation in disequilibrium with livestock grazing: Evidence from long-term exclosures, Austral Ecol., 38, 57-65, 2013. 
Smith, D. M. S., McKeon, G. M., Watson, I. W., Henry, B. K., Stone, G. S., Hall, W. B., and Howden, S. M.: Learning from episodes of degradation and recovery in variable Australian rangelands, P. Natl. Acad. Sci. USA, 104, 20690-20695, 2007.

Smith, J. G., Eldridge, D. J., and Throop, H. L.: Landform and vegetation patch type moderate the effects of grazing-induced disturbance on carbon and nitrogen pools in a semi-arid woodland, Plant Soil, 360, 405-419, 2012.

State of Queensland: Reef Water Quality Protection Plan Secretariat: First Report Card 2009 Baseline Brisbane, QLD, 2011.

Stavi, I. and Lal, R.: Achieving Zero Net Land Degradation: Challenges and opportunities, J. Arid Environ., 112, 44-51, 2015.

Stoms, D. M. and Hargrove, W. W.: Potential NDVI as a baseline for monitoring ecosystem functioning, Int. J. Remote Sens., 21, 401-407, 2000.

Stone, G., Bruget, D., Carter, J., Hassett, R., McKeon, G., and Rayner, D.: Land: Pasture production and condition, Department of Natural Resources and Water, Queensland Government, 2007.

Su, Y. Z., Li, Y. L., Cui, H. Y., and Zhao, W. Z.: Influences of continuous grazing and livestock exclusion on soil properties in a degraded sandy grassland, Inner Mongolia, northern China, Catena, 59, 267-278, 2005.

Thackway, R. and Lesslie, R.: Vegetation Assets, States and Transitions (VAST): accounting for vegetation condition in the Australian landscape, Bureau of Rural Sciences, Canberra, 2005.

UNCCD: United Nations convention to combat desertification in countries experiencing serious drought and/or desertification, particularly in Africa, United Nations General Assembly, New York, 1994.

UNCCD: UNCCD Secretariat Policy Brief on Zero Net Land Degradation - a Sustainable Development Goal for Rio+20, United Nations Convention to Combat Desertification (UNCCD), Bonn, Germany, 2012.
UNEP: World Atlas of Desertification, Arnold \& Wiley, on behalf of UNEP, London, New York, 1997.

Visser, H. and de Nijs, T.: The Map Comparison Kit, Environ. Modell. Softw., 21, 346-358, 2006.

Walker, B. H. and Janssen, M. A.: Rangelands, pastoralists and governments: interlinked systems of people and nature, Philos. T. R. Soc. Lon. B, 357, 719-725, 2002.

Webb, N. P., Phinn, S. R., and McGowan, H. A.: Visual assessment of the Australian Land Erodibility Model, J. Arid Environ., 73, 678-682, 2009.

Wessels, K. J., Prince, S. D., Malherbe, J., Small, J., Frost, P. E., and VanZyl, D.: Can human-induced land degradation be distinguished from the effects of rainfall variability? A case study in South Africa, J. Arid Environ., 68, 271-297, 2007.

Wessels, K. J., Prince, S. D., and Reshef, I.: Mapping land degradation by comparison of vegetation production to spatially derived estimates of potential production, J. Arid Environ., 72, 1940 1949, 2008.

Weymouth, G., Mills, G. A., Jones, D., Ebert, E. E., and Manton, M. J.: A continental-scale daily rainfall analysis system, Aust. Meteorol. Mag., 48, 169-179, 1999.

Whish, G. (Ed.): Land types of Queensland, Version 2.0, Prepared by the Grazing Land Management Workshop Team, Department of Employment, Economic Development and Innovation, Brisbane, PR07-3212. 2011.

Zika, M. and Erb, K. H.: The global loss of net primary production resulting from human-induced soil degradation in drylands, Ecol. Econ., 69, 310-318, 2009. 